\title{
Pediatric dural venous sinus thrombosis following closed head injury: an easily overlooked diagnosis with devastating consequences
}

\author{
Joe M Das, MCh., Rashmi Sapkota, Binjura Shrestha
}

Department of Neurosurgery, College of Medical Sciences - Teaching Hospital, Bharatpur-10, Chitwan-Nepal

\begin{abstract}
Dural venous sinus thrombosis (DVST) is an uncommon finding after traumatic brain injury. The diagnosis can often be initially missed, particularly if not associated with an overlying fracture. Pediatric DVST following closed head injury and without an overlying fracture is very rare, with only 20 cases reported in the literature to date. Here we present the case of a 19-month-old boy who presented with a history of trivial fall and an episode of fever. On presentation, the pediatric Glasgow Coma Scale (pGCS) score was E3V4M6, and initial brain computed tomography (CT) was normal. He was initially conservatively managed. However, subsequent $\mathrm{CT}$, taken following an episode of seizure, revealed right tentorial subarachnoid hemorrhage and falx hematoma. Conservative management was continued till he started developing recurrent seizures with a decrease in PGCS scores. Repeat CT revealed sinus thrombosis that involved the posterior aspect of the superior sagittal sinus with a massive brain edema. The coagulation profile was normal, and no fracture overlying the sinus was observed.Although he underwent emergency bifrontal decompressive craniotomy, he did not recover. This study emphasizes on the importance of not missing the diagnosis of sinus thrombosis and the devastating consequences that can occur if it is overlooked.
\end{abstract}

Keywords: Child; closed head injuries; cranial venous sinus thrombosis; decompressive craniectomy; early post-traumatic seizures.

\section{INTRODUCTION}

Although dural venous sinus thrombosis (DVST) is observed in $4 \%$ of patients following penetrating head injury, it is rare following closed head injury. ${ }^{[1]}$ In closed head injuries, DVST is usually associated with a fracture overlying the sinus. The occurrence of DVST without an overlying fracture is quite unique, particularly in the pediatric population, with only 20 cases reported in the literature to date. ${ }^{[2,3]}$ Management guidelines are not clearly defined for such cases because of the rarity of the condition. Thus, if not carefully considered, the diagnosis of DVST can often be missed.

\section{CASE REPORT}

A 19-month-old boy who was born at full-term via normal de- livery and had normal developmental mile stones presented to our emergency room (ER) following a 4-h history of fall from one stair height. He was referred from a secondary care hospital, where he had an episode of fever. There was no history of loss of consciousness, vomiting, seizures, nasal bleed, earache, or ear discharge. He did not have any previous illness or hospital admissions. On reaching the ER, his pediatric Glasgow Coma Scale (pGCS) score (Table I) was E3V4M6, and his pupils were bilaterally equal and reacted to light. There was no asymmetry of limb movements. He did not have any external injury, and no features of chest or abdominal injury was observed. He underwent brain computed tomography (CT) at the previous hospital, which was reported as normal. Hence, he was managed by the Department of Pediatrics and was examined to rule out infective causes of fever and altered sensorium. Almost $15 \mathrm{~h}$ after the trauma, he started

Cite this article as: Das JM, Sapkota R, Shrestha B. Pediatric dural venous sinus thrombosis following closed head injury: an easily overlooked diagnosis with devastating consequences. Ulus Travma Acil Cerrahi Derg 2018;24:74-7

Address for correspondence: Joe M Das, MCh.

Adres bilgisi: Dept. of Neurosurgery, College of Medical Sciences, Teaching Hospital, P.O. Box: 23, Bharatpur-10 Chitwan, Nepal.

Tel: +9779802998899 E-mail: drjoemdas@gmail.com

Ulus Travma Acil Cerrahi Derg 2018;24(I):74-77 DOI: 10.5505/tjtes.2017.22823 Submitted: 04.06.2017 Accepted: 01.1I.2017

Copyright 2018 Turkish Association of Trauma and Emergency Surgery 
Table I. Pediatric Glasgow Coma Scale (pGCS) score ${ }^{[10]}$

\begin{tabular}{|c|c|c|c|c|}
\hline & & $>$ I year & $<$ l year & \\
\hline \multirow[t]{4}{*}{ Eye opening } & 4 & Spontaneously & Spontaneously & \\
\hline & 3 & To verbal command & To shout & \\
\hline & 2 & To pain & To pain & \\
\hline & $\mathrm{I}$ & No response & No response & \\
\hline \multirow[t]{7}{*}{ Best motor response } & 6 & Obeys & Spontaneous movements & \\
\hline & 5 & Localizes pain & Localizes pain & \\
\hline & 4 & Flexion-withdrawal & Flexion-withdrawal & \\
\hline & 3 & Abnormal flexion & Abnormal flexion & \\
\hline & 2 & Abnormal extension & Abnormal extension & \\
\hline & I & No response & No response & \\
\hline & & $>5$ years & $2-5$ years & 0-23 months \\
\hline \multirow[t]{5}{*}{ Best verbal response } & 5 & Oriented and converses & Appropriate words and phrases & Coos and smiles appropriately \\
\hline & 4 & Disoriented and converses & Inappropriate words & Cries \\
\hline & 3 & Inappropriate words & Cries and/or screams & Inappropriate crying and/or screaming \\
\hline & 2 & Incomprehensible sounds & Grunts & Grunts \\
\hline & I & No response & No response & No response \\
\hline
\end{tabular}

developing generalized tonic-clonic seizures, refractory to phenytoin. Hence, he was transferred to the Neurosurgery Intensive Care Unit. Repeat brain CT (Fig. I) revealed rightsided tentorial subarachnoid hemorrhage (SAH) and falx hematoma. Parenteral sodium valproate was initiated, and his seizures were controlled. On the next day, his pGCS score was E2V3M6, and breast feeding was initiated. He was active
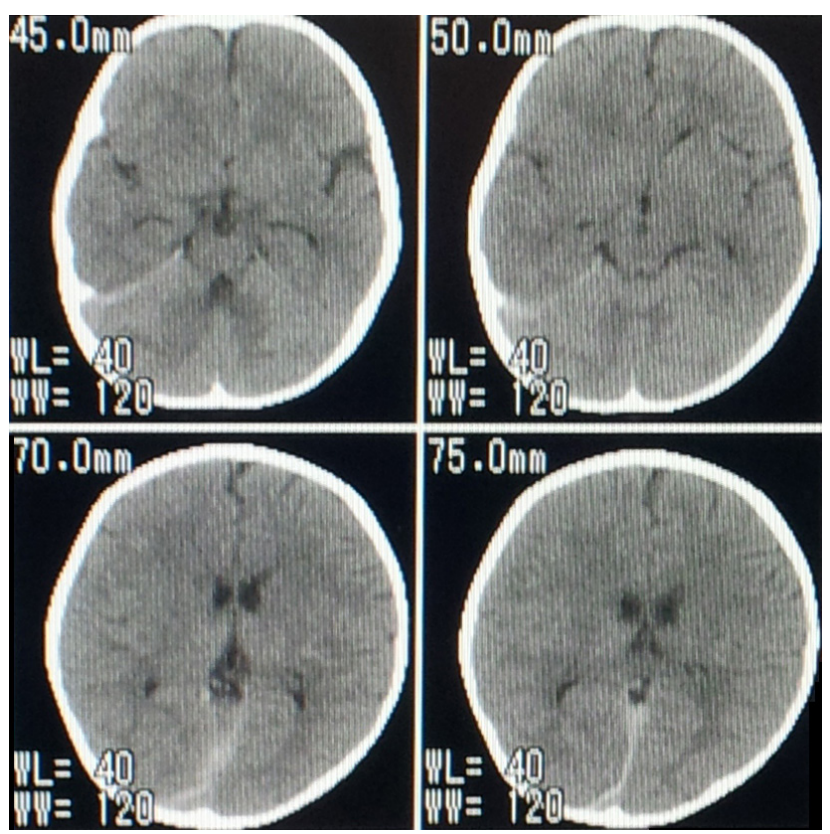

Figure 1. Non-contrast axial computed tomography (CT) of the brain showing right-sided tentorial subarachnoid hemorrhage and falx hematoma. till the third post-trauma day, when he developed another episode of right-sided focal seizures. Midazolam was initiated as an add-on anticonvulsant, following which the seizures were controlled. Repeat plain brain CT (Fig. 2a) revealed a massive cerebral edema with diffuse hypoxic injury. Contrastenhanced CT brain (Fig. 2b) showed a sinus thrombosis that involved the posterior aspect of the superior sagittal sinus.
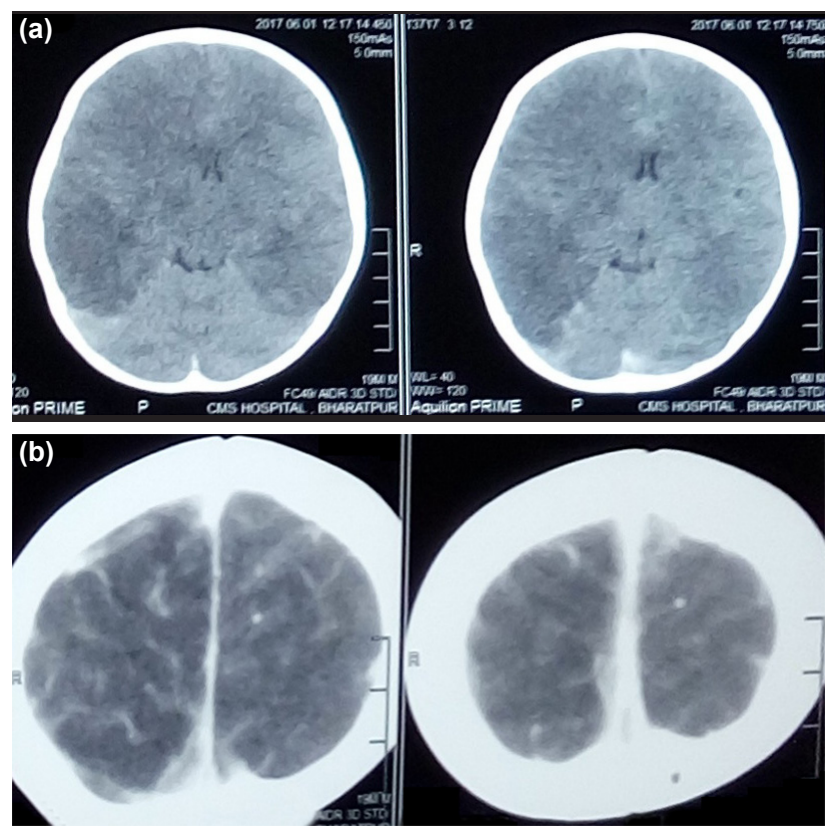

Figure 2. (a) Non-contrast axial CT of the brain showing diffuse brain edema and effacement of ventricles. (b) Contrast-enhanced axial CT of the brain showing the thrombosed superior sagittal sinus. 


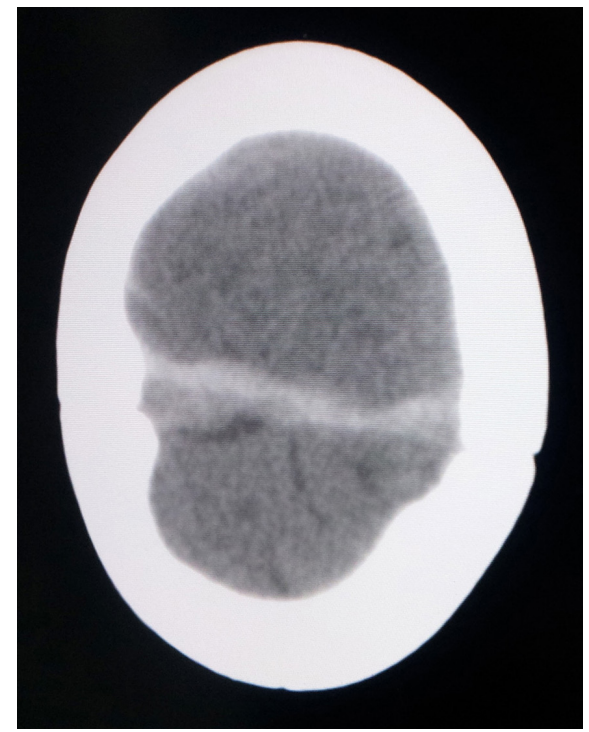

Figure 3. Retrospective analysis of initial non-contrast CT of the brain showing hyperdense superior sagittal sinus.

We could not wait for magnetic resonance imaging (MRI) of the brain. His platelet count, prothrombin time-International Normalized Ratio, bleeding time, and clotting time were all normal. He underwent emergency bifrontal decompressive craniotomy with falx duraplasty. The brain was full and pulsatile. The patient was postoperatively ventilated. However, before we could perform postoperative $\mathrm{CT}$, he suffered a cardiac arrest at $6 \mathrm{~h}$ after the surgery and he could not be resuscitated. On subsequent retrospective analysis of the second CT (Fig. 3) in the console, we noticed that the superior sagittal sinus was completely thrombosed. Usually in CT images, the top-most axial cuts are not included; hence, the diagnosis can be missed because the superior sagittal sinus may sometimes be clearly observed in such cuts only.

\section{DISCUSSION}

Although the exact incidence of DVST following head injury remains unknown, it is believed to occur in up to $4 \%$ of patients with penetrating head injuries. DVST is rare following closed head injuries, particularly injuries that are mild. The exact cause of sinus thrombosis after a closed head injury is unknown. However, the following factors may be responsible. ${ }^{[4]}$

I. Injury to the wall of the dural sinus

2. Inward extension of the thrombosis from injured emissary veins

3. Intramural hemorrhage with subsequent injury to the lining endothelium

DVST is rare in children, with an incidence of 0.07 in 100,000. Antithrombin defects, protein $\mathrm{C}$ and $\mathrm{S}$ defects, and factor $\mathrm{V}$ gene defect (associated with activated protein $C$ resistance) are common predisposing factors for DVST in the pediatric population. Polycythemia and congenital heart diseases can also predispose to DVST. ${ }^{[5]}$
Posttraumatic DVST is a rare condition that is associated with high morbidity and mortality. The sinus thrombosis is often missed in plain brain CT images. However, careful study of non-contrast-enhanced CT images may often reveal hyperdensity of the sinus, ${ }^{[6]}$ as in this case, although we initially missed it. The diagnosis is quite often revealed on retrospection and careful analysis of the situation. ${ }^{[7]}$ This needs to be confirmed with contrast -enhanced CT or MRI.

We propose that DVST should be suspected in a patient with a head injury when one or more of the following red flag signs are observed.

I. Persistent focal seizures refractory to usual anticonvulsants

2. Brain $C T$ showing features of tentorial and falx $S A H$

3. GCS that does not improve in a patient with tentorial or falx SAH

4. Fever occurs within $12 \mathrm{~h}$ of head injury

5. Persistent giddiness or vomiting ${ }^{[8]}$

6. Late deterioration in a patient's clinical condition ${ }^{[9]}$

This study underscores the importance of interpreting brain $\mathrm{CT}$ in patients with traumatic head injury, particularly those with the red flag signs as mentioned above. DVST, if left alone, can lead to morbidity and mortality owing to an increased intracranial pressure secondary to venous infarct.

Conflict of interest: None declared.

\section{REFERENCES}

1. Muthukumar N. Uncommon cause of sinus thrombosis following closed mild head injury in a child. Childs Nerv Syst 2005;21:86-8. [CrossRef]

2. Beer-Furlan A, de Almeida CC, Noleto G, Paiva W, Ferreira AA, Teixeira MJ. Dural sinus and internal jugular vein thrombosis complicating a blunt head injury in a pediatric patient. Childs Nerv Syst 2013;29:1231-4.

3. Wilcher J, Pannell M. Dural Sinus (Cerebral Venous) Thrombosis in a Pediatric Trauma Patient: A Rare Complication After Closed Head Injury. Pediatr Emerg Care 2016;32:872-4. [CrossRef]

4. Ochagavia AR, Boque MC, Torre C, Alonso S, Sirvent JJ. Dural venous sinus thrombosis due to cranial trauma. Lancet 1996;347:1564. [CrossRef]

5. Reith W. The Brain. In: Vogl TJ, Reith W, Rummery EJ, editors. Diagnostic and Interventional Radiology. 1st ed. Berlin: Springer; 2016. p. 131-2. [CrossRef]

6. Rao KC, Knipp HC, Wagner EJ. Computed tomographic findings in cerebral sinus and venous thrombosis. Radiology 1981;140:391-8.

7. Khursheed N, Altaf R, Furqan N, Wani A, Jain A, Ali Y. Post-traumatic sagittal sinus thrombosis: case report. Ulus Travma Acil Cerrahi Derg 2013;19:69-72. [CrossRef]

8. Yuen HW, Gan BK, Seow WT, Tan HK. Dural sinus thrombosis after minor head injury in a child. Ann Acad Med Singapore 2005;34:639-41.

9. Dobbs TD, Barber ZE, Squier WL, Green AL. Cerebral venous sinus thrombosis complicating traumatic head injury. J Clin Neurosci 2012;19:1058-9. [CrossRef]

10. Campbell JE. Trauma scoring in the prehospital setting. In: International Trauma Life Support - For Prehospital Care Providers. 1st ed. India: Dorling Kindersley; 2009. p. 382. 


\section{OLGU SUNUMU - ÖZET}

\section{Kapalı kafa travması sonrası pediyatrik dural venöz sinüs trombozu: Kötï sonuçları olan ve kolayca atlanan bir tanı}

\section{Dr. Joe M Das, Rashmi Sapkota, Binjura Shrestha}

Tıp Bilimleri Koleji, Sinir Cerrahisi Anabilim Dalı, Eğitim Hastanesi, Bharatpur-10, Chitwan-Nepal

Travmatik beyin yaralanması sonrası dural venöz sinüs trombozu (DVST) sık görülmeyen bir bulgudur. Başlangıçta tanı özellikle üstünde bir kırık yoksa sıklıkla atlanabilir. Üstünde kırık olmayan pediyatrik DVST çok ender olup literatürde bu tarihe kadar yalnızca 20 olgu bildirilmiştir. Burada önemsiz bir düşme ve bir febril epizot öyküsü olan 19 aylık bir erkek çocuğu sunuyoruz. Bize geldiğinde Glasgow Koma Skalası skoru (pGKS) E3V4M6 olduğu gibi beynin bilgisayarlı tomografi (BT) taraması normaldi. Başlangıçta konservatif tedavi edildi. Ancak bir nöbet sonrası çekilen müteakip BT taraması tentoriyumda subaraknoid kanama ve falks hematomunu gösterdi. pGKS'de düşüşle birlikte yinelenen nöbetleri gelişmeye başlayana kadar konservatif tedaviye devam edildi. Yinelenen BT taraması masif beyin ödemiyle birlikte süperiyor sagital sinüsün arka yüzünü etkileyen sinüs trombozunu açığa çıkardı. Koagülasyon profili normaldi ve sinüsün üzerinde kırık yoktu. Acil bifrontal dekompressif kraniyektomi uygulanmasına rağmen hasta kurtarılamadı. Bu olgu sunumu, sinüs tanısını atlamamanın ve atlandığı takdirde yıkıcı sonuçlara yol açabilen bu patolojinin önemini vurgulamaktadır.

Anahtar sözcükler: Çocuk; dekompressif kraniyektomi; erken posttravmatik nöbetler; kapalı kafa travması; kraniyal venöz sinüs trombozu.

Ulus Travma Acil Cerrahi Derg 2018;24(I):74-77 doi: 10.5505/tjtes.2017.22823 